\title{
Production and Marketing Patterns of Pearl Millet in India with Special Reference to Haryana
}

\author{
K.K. Kundu*, Dinesh Kumar and Sumit \\ Department of Agricultural Economics, CCS HAU, Hisar, Haryana, India \\ *Corresponding author
}

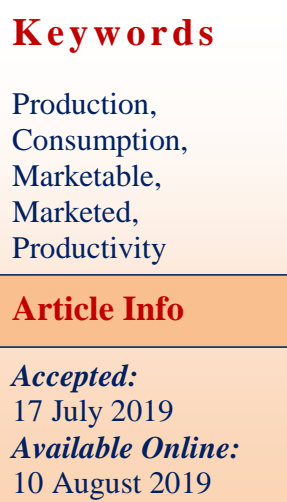

A B S T R A C T

This study is based on the data collected from a sample of 120 farmers selected from amongst the selected villages within the selected markets/mandis. The whole sample design consists of multistage random sampling. The selection of the district forms the first stage in sampling. Bhiwani and Mahindergarh districts of Haryana were purposively selected to represent a case study. These markets are selected because these market were the vicinity of the research. One block was selected from each selected district of Mahandragarh and Bhiwani. The block was selected based on higher area under the pearl millet. From the district Bhiwani block Siwani was selected and from the district Mahindergarh block Mahindergarh was selected. From each selected block, two villages were randomly selected. All the pearl millet cultivators of the four selected villages were selected according to their size of operational holdings. They were divided into four size groups and these groups were categorized on the basis of their land holdings i.e. marginal, small, medium and large. The time series and cross sectional data was collected. In contrast, production is increasing in both Haryana and Rajasthan by more than 4per cent per annum.It was assumed that the Stover productivity was at 2.5 time that of grain yield, and it was the same across all state and season, which was the average of previous five years Stover to grain yield ratio. It was assumed that per capita consumption of 2004/05 level would be maintained by both urban and rural population in 2011 and 2020. With the increase in the size of holding among the different component of the total consumption, Livestock consumption forms the major portion constituting 54.15 per cent and 51.63 per cent of total consumption followed by family consumption i.e. 30.68 per cent and 30.69 per cent in Mahindergarh and Bhiwani districts, respectively. 


\section{Introduction}

Pearl millet (Pennisetum glaucum) is a nutritious cereal cultivated as rain-fed crop. It has significant potential as feed and food grain in addition to its current use as fodder. Pearl millet grains contain 10 to 12 per cent protein, higher concentration of essential amino acids and higher gross energy. Consequently, its grain is not only used as a food but also used as feed for the poultry, cattle and swine. Pearl millet is also used for extracting the ethanol from its grains and thus it is of industrial use. Its economic importance is significant especially in semi-arid tropical zones of Rajasthan, Gujarat and Haryana in India. Again, its importance in mixed farming is also well documented. Pearl millet is the next most important millet crop in India in terms of area and production after sorghum. India is also considered the secondary centre of origin for pearl millet with many distinct cultivars being grown throughout the country.

The area under pearl millet crop in Haryana was 7.73 lakh hectares during the year 196566 , which declined to 5.85 lakh hectares in the year 2009-10. However, the yield has increased significantly over the above mentioned period. The growth in yield is significantly higher in Haryana. The production of pearl millet in Haryana has been increased from 2.06 lakh tonnes during the year 1965-66 to 9.32 lakh tonnes during 200910 and the productivity increased from 267 to $1593 \mathrm{~kg} / \mathrm{ha}$ during the same period. This has increased further to $2069 \mathrm{~kg} / \mathrm{ha}$ during the year 2011-12

In Haryana, the maximum area under pearl millet was in Bhiwani district followed by Mahendergarh, Rewari and Hisar districts during the year 2008-09. Studies on the marketed and marketable surplus have also been received attention by large number of economists in the recent years. The importance of marketed and marketable surplus has greatly increased owing to the recent changes in agricultural technology as well as social pattern. Realizing the importance of accurate knowledge about marketing, it becomes essential to examine the pattern of production, consumption and marketable and marketed surplus, besides the trends of arrivals and prices of pearl millet on different farm sizes to provide an empirical base for smooth flow of produce from producer to consumer. An increasing proportion of its rising output should come to the market for the benefit of pearl millet growers and weaker sections of the community (Statistical abstract of Haryana, 2010-11).

The vital role of marketed and marketable surplus of agricultural products in economic development of a developing economy like India can hardly be over emphasized. Surplus from agriculture has been used as leverage for promoting industrialization in pre-dominantly agrarian economies. Thus, the rate at which agricultural production expands affording an increasing supply of food and raw materials, largely determines the pace of economic development. In view of high rate of population, the growth and high marginal propensity to consume, most of the increase in pearl millet production is utilized by the producers themselves for human and livestock utilized. Thus, the study of marketed and marketable surplus in the economic system is more important than the mere increase in agricultural production to find ways to increase the tempo of marketed surplus. There exists a considerable complimentary relationship between agriculture and industry. Surpluses from agriculture influence the volume of non-farm employment. The food surplus in particular and agriculture surplus in general, determine the nature and tempo of opportunities for non-farm employment and income generation (Minocha, 1962). 


\section{Materials and Methods}

This study is based on the data collected from a sample of 120 farmers selected from amongst the selected villages within the selected markets/mandis. The whole sample design consists of multistage random sampling. The selection of the district forms the first stage in sampling. Bhiwani and Mahindergarh districts of Haryana were purposively selected to represent a case study. These markets are selected because these market were the vicinity of the research. One block was selected from each selected district of Mahandragarh and Bhiwani. The block was selected based on higher area under the pearl millet. From the district Bhiwani block Siwani was selected and from the district Mahindergarh block Mahindergarh was selected. From each selected block, two villages were randomly selected. All the pearl millet cultivators of the four selected villages were selected according to their size of operational holdings.

They were divided into four size groups and these groups were categorized on the basis of their land holdings i.e. marginal, small, medium and large. the primary data collected pertains to the year 2013-14. The time series and cross sectional data were also collected.

\section{Results and Discussion}

Economic development of a nation rests mainly upon the quantum of its marketed and marketable surplus.

The marketable and marketed surplus plays a significant role for economic development in a developing economy to meet the requirement of food, feed, fodder and raw material of nonfarm and urban population as the industrialization and urbanization is likely to increase rapidly.
In recent time importance of estimating marketed and marketable surplus of major food grains need no over emphasis in a developing country like India. In this section, an attempt has been made to examine the carry over stock, production, and consumption pattern, marketed and marketable surplus of pearl millet on different farm sizes and to study the factor affecting the marketed and marketable surplus.

Marketable surplus represents the surplus left with the farmer for disposal after his genuine requirements of family consumption, feed, seed and other obligations have been met. Marketed surplus represent only that portion of produce, which is actually marketed and is placed at the disposal of non-farming rural population and urban consumers.

\section{Production, consumption, marketable and marketed surplus of pearl millet}

Table 1 reveals that North-western India account for 72 per cent of area under pearl millet and 66per centof its production. Yield levels are the lowest in Rajasthan $(650 \mathrm{~kg} / \mathrm{ha})$ while it is 1352 and 1733 hundred in Gujarat and Haryana, respectively. Haryana has high yield rates because more than 40per cent of the area under pearl millet is irrigated (partially with supplemental irrigation). In Gujarat most of the summer pearl millet area is irrigated which contributes high overall yields.

In Rajasthan in contrast, the bulk of the pearl millet is grown in rain fed condition and landraces still account for close 50per cent of total area in western districts.In contrast, production is increasing in both Haryana and Rajasthan by more than 4per cent per annum.Similar type of result wasobserved to in accordance with Reddy et al.,(2013). Table 2 reveals thatin the case of Haryana $(3.23 \%)$ and Rajasthan (5.29\%), only yield growth rate 
was considered forecast production as it was assumed that area contribution to production growth would be negligible (zero) in future. This was done since the focus group discussions had reveals that the sustained growth area under pearl millet is difficult to achieve the Stover. Production was forecasted based on expected growth rate in grain production.

It was assumed that the Stover productivity was at 2.5 time that of grain yield, and it was the same across all state and season, which was the average of previous five years Stover to grain yield ratio calculate from cost of cultivation data for all three states (Directorate of economics and statistics, 2011). Similar type of result was observed to in accordance with Reddy et al., (2013). Table 3 reveals that consumption estimates for the year 2011 and 2020 were projected based on the per capita consumption in year 2004/05 base on NSSO $61^{\text {st }}$ round and the census population for the year 2011 and projected population for the year 2020 (national commission on population, 2006). It was assumed that per capita consumption of 2004/05 level would be maintained by both urban and rural population in 2011 and 2020. This assumption was based on the recent policy development that the introduction of the pearl millet in the PDS food security bill (2011) arrests the decline in per capita consumption over the period.

Table.1 Pearl millet area, production and yield, 2007-09 and their compound annual growth rates (1990-2009)

\begin{tabular}{|l|c|c|c|c|c|c|}
\hline Region/State & $\begin{array}{c}\text { Area } \\
(\mathbf{0 0 0} \text { ha) }\end{array}$ & $\begin{array}{c}\text { Growth } \\
\text { rate (\%) }\end{array}$ & $\begin{array}{c}\text { Production } \\
(\mathbf{0 0 0} \text { tons) }\end{array}$ & $\begin{array}{c}\text { Growth } \\
\text { rate (\%) }\end{array}$ & Yield (kg/ha) & $\begin{array}{c}\text { Growth } \\
\text { rate (\%) }\end{array}$ \\
\hline Western India & $6513(72)$ & 0.003 & $5600(66)$ & 3.12 & 860 & 3.1 \\
\hline Haryana & $610(7)$ & 0.25 & $1057(13)$ & 4.49 & 1733 & 4.24 \\
\hline Rajasthan & $5139(57)$ & 0.45 & $3511(42)$ & 4.17 & 683 & 3.7 \\
\hline Gujarat & $764(8)$ & -2.4 & $1032(12)$ & -0.3 & 1352 & 2.15 \\
\hline All India & $9080(100)$ & -3.62 & $8455(100)$ & 1.82 & 931 & 2.46 \\
\hline
\end{tabular}

Note: Figures in parenthesis indicates share to all- India

Source: Prospects for kharif and summer pearl millet in western India (ICRISAT)

Table.2 Growth rates of pearl millet area, production and yield (1997-2009)

\begin{tabular}{|c|c|c|c|c|}
\hline & Haryana & Rajasthan & Gujarat & Western India \\
\hline \multicolumn{5}{|l|}{ TE 2008 (mean) } \\
\hline Area (1000 ha) & 762 & 163 & 925 & 6512 \\
\hline Production $(1000 \mathrm{t})$ & 955 & 3468 & 1133 & 5555 \\
\hline Yield (kg/ha) & 1546 & 696 & 1225 & 852 \\
\hline \multicolumn{5}{|l|}{ ACGR 1997-2009 } \\
\hline Area $(\%)$ & 0.45 & 1.16 & -1.3 & 0.71 \\
\hline Production (\%) & 3.67 & 6.45 & -0.64 & 4.22 \\
\hline Yield (\%) & 3.23 & 5.29 & 0.66 & 3.51 \\
\hline
\end{tabular}

Source: Directorate of economics and statistics 
Table.3 Population projection and per capita consumption of pearl millet

\begin{tabular}{|c|c|c|c|c|}
\hline \multirow[t]{2}{*}{ State } & \multirow[t]{2}{*}{ Urban/Rural } & \multicolumn{2}{|c|}{ Population (million) } & \multirow{2}{*}{$\begin{array}{c}\text { Consumption in TE 2004/05 } \\
\text { (kg/capita/annum) }\end{array}$} \\
\hline & & 2011 & 2020 & \\
\hline \multirow[t]{3}{*}{ Haryana } & Urban & 8.8 & 11.1 & 0.4 \\
\hline & Rural & 16.5 & 17.9 & 5 \\
\hline & Total & 25.4 & 29 & 3.4 \\
\hline \multirow[t]{3}{*}{ Rajasthan } & Urban & 17.1 & 18.7 & 6.9 \\
\hline & Rural & 51.5 & 58 & 33 \\
\hline & Total & 68.6 & 76.8 & 26.5 \\
\hline \multirow{3}{*}{ Gujarat } & Urban & 25.7 & 28.2 & 7.3 \\
\hline & Rural & 34.7 & 37.3 & 28.1 \\
\hline & Total & 60.4 & 65.5 & 19.2 \\
\hline \multirow{3}{*}{ Western India } & Urban & 51.6 & 58 & 6 \\
\hline & Rural & 102.7 & 113.3 & 26.8 \\
\hline & Total & 154.4 & 171.3 & 19.9 \\
\hline
\end{tabular}

Source: GOI 2011, population projections are based on report of the technical group on population projections

Table.4 Percentage share of different uses of pearl millet grain in 2011 and 2020

\begin{tabular}{|l|l|c|c|c|c|}
\hline Year & Utilization & Haryana & Rajasthan & Gujarat & Western India \\
\hline $\mathbf{2 0 1 1}$ & Food grain & 10.6 & 46.3 & 58.1 & 45.6 \\
\hline & Cattle feed & 39.2 & 39.3 & 33.5 & 37.5 \\
\hline & Poultry feed & 34.1 & 3.5 & 5.4 & 7.7 \\
\hline & Brewery and other non-food uses & 15.8 & 10.4 & 2.8 & 8.8 \\
\hline & Seed & 0.3 & 0.5 & 0.2 & 0.4 \\
\hline & Total & 100 & 100 & 100 & 100 \\
\hline $\mathbf{2 0 2 0}$ & Food grain & 8.3 & 41.3 & 52.5 & 40 \\
\hline & Cattle feed & 35.8 & 40.2 & 36.5 & 38.6 \\
\hline & Poultry feed & 37 & 4.3 & 7 & 9.4 \\
\hline & Brewery and other non-food uses & 18.7 & 13.8 & 3.9 & 11.7 \\
\hline & Seed & 0.2 & 0.4 & 0.1 & 0.3 \\
\hline & Total & 100 & 100 & 100 & 100 \\
\hline
\end{tabular}

Source: Prospects for kharif and summer pearl millet in western India (ICRISAT)

Table.5 Trends in consumption of pearl millet

\begin{tabular}{|l|c|l|}
\hline Consumption of pearl millet & Response (\%) & Reasons for decrease in consumption \\
\hline Increased & 15 & 1. Difficulty in preparation of dough \\
\hline Decreased & 70.5 & 2. Cheap and readily available rice/wheat \\
\hline Constant & 14.5 & 3. Longer cooking time \\
\hline Total & 100 & 4. Readily available fast foods \\
\hline
\end{tabular}


Table.6 Production, consumption, marketable and marketed surplus of pearl millet in Mahindergarh district

\begin{tabular}{|c|c|c|c|c|c|}
\hline Items / category & Marginal & Small & Medium & Large & Overall \\
\hline Total production & 1585 & 3371 & 6606 & 11975 & 5884.25 \\
& $(100)$ & $(100)$ & $(100)$ & $(100)$ & $(100)$ \\
\hline Total consumption & 286 & 384 & 594 & 900 & 541 \\
& $(18.04)$ & $(11.39)$ & $(8.99)$ & $(7.51)$ & $(9.19)$ \\
\hline Marketable surplus & 1299 & 2987 & 6012 & 11075 & 5343.25 \\
& $(81.96)$ & $(88.61)$ & $(91.01)$ & $(92.49)$ & $(90.80)$ \\
\hline Marketed surplus & 1299 & 2987 & 6012 & 11075 & 5343. \\
& $(81.96)$ & $(88.61)$ & $(91.01)$ & $(92.49)$ & $25(90.80)$ \\
\hline
\end{tabular}

Figures in parenthesis are the percentage of total production

Table.7 Production, consumption, marketable and marketed surplus of pearl millet in Bhiwani district

(kg per farm)

\begin{tabular}{|l|c|c|c|c|c|}
\hline Items & Marginal & Small & Medium & Large & Overall \\
\hline Total production & 1154 & 3002 & 6262 & 10990 & 5352 \\
& $(100)$ & $(100)$ & $(100)$ & $(100)$ & $(100)$ \\
\hline Total consumption & 206 & 380 & 825 & 1475 & 721.50 \\
& $(17.85)$ & $(12.69)$ & $(13.17)$ & $(13.42)$ & $(13.47)$ \\
\hline Marketable surplus & 948 & 2621 & 5437 & 9515 & 4630.25 \\
& $(82.15)$ & $(87.31)$ & $(86.83)$ & $(86.58)$ & $(86.51)$ \\
\hline Marketed surplus & 948 & 2621 & 5437 & 9515 & 4630.25 \\
& $(82.15)$ & $(87.31)$ & $(86.83)$ & $(86.58)$ & $(86.51)$ \\
\hline
\end{tabular}

Figures in parenthesis indicate percentage of total production

Table.8 Production and consumption pattern of pearl millet among different size groups in Mahindergarh disitrict

(kg per farm)

\begin{tabular}{|l|c|c|c|c|c|}
\hline \multicolumn{1}{|c|}{ Items } & \multicolumn{3}{c|}{ Size groups } \\
\cline { 2 - 6 } & Marginal & Small & Medium & Large & Overall \\
\hline Total production & 1585 & 3371 & 6606 & 1197 & 5884.25 \\
\hline Total consumption & 286 & 384 & 594 & 900 & 541 \\
& $(100)$ & $(100)$ & $(100)$ & $(100)$ & $(100)$ \\
\hline Livestock feed & 176 & 228 & 368 & 400 & 293 \\
& $(61.54)$ & $(59.38)$ & $(61.95)$ & $(44.44)$ & $(54.15)$ \\
\hline Family consumption & 110 & 128 & 175 & 250 & 165.5 \\
& $(38.46)$ & $(33.33)$ & $(29.47)$ & $(27.78)$ & $(30.69)$ \\
\hline Wages in kind & 0 & 28 & 51 & 250 & 82 \\
& $(0.00)$ & $(7.29)$ & $(8.58)$ & $(27.78)$ & $(15.16)$ \\
\hline
\end{tabular}

Figures in parenthesis indicate percentage of total consumption 
Table.9 Production and consumption pattern of pearl millet among different size groups in Bhiwani disitrict

\begin{tabular}{|l|c|c|c|c|c|}
\hline \multicolumn{1}{|c|}{ Items } & \multicolumn{5}{c|}{ Size groups } \\
\cline { 2 - 6 } & Marginal & Small & Medium & Large & Overall \\
\hline a) Total production & 1154 & 3002 & 6262 & 10990 & 5352 \\
\hline Total consumption & 206 & 380 & 825 & 1475 & 721.25 \\
& $(100)$ & $(100)$ & $(100)$ & $(100)$ & $(100)$ \\
\hline a) Livestock & 125 & 215 & 400 & 750 & 372.50 \\
& $(60.68)$ & $(56.58)$ & $(48.49)$ & $(50.85)$ & $(51.63)$ \\
\hline b) Family consumption & 81 & 155 & 275 & 375 & 221.25 \\
& $(39.32)$ & $(40.79)$ & $(33.33)$ & $(25.42)$ & $(30.69)$ \\
\hline c) Wages in kind & 0 & 10 & 150 & 350 & 127.50 \\
& $(0.00)$ & $(2.63)$ & $(18.18)$ & $(23.73)$ & $(17.68)$ \\
\hline
\end{tabular}

Figures in parenthesis indicate percentage of total consumption

Table 4 reveals that overall 2011, 45.60 per cent of production of pearl millet grain goes for food use, 37.50per cent for cattle feed, 7.70 poultry feed, 8.8 per cent to alcohol industry and only 0.40per cent for seed purpose. The projected relative share of different uses by 2020 showed that the share of cattle feed will increase to 38.60 per cent, share of poultry feed will be increased 9.40per cent, share of alcohol industry and other non-food uses will be increased to 11.7per cent, while food uses will decrease to 40per cent The food share is high in Gujarat and Rajasthan, while share of cattle feed and poultry fee in much higher in Haryana.

Table 5 showed trends in consumption of pearl millet over last few years. Majority of respondent $(70.50 \%)$ reported that consumption of pearl millet declined over time reportedly due to difficulty in preparation of dough, longer cooking time, cheap and readily available rice/wheat and readily available fast food.

Table 6 and 7 reveals that overall production of all the farm sizes was observed to be $5884.25 \mathrm{~kg}$ per acre in Mahindergarh and $5352 \mathrm{~kg}$ per acre in Bhiwani district which was more than as in case of marginal and small farmers, whereas it is lower than as that of medium and large farmers.

Total production showed a tendency to increase with increase in farm size. Total consumption of pearl millet on farm was estimated as 9.19 per cent of total production in Mahindergarh and 13.48 per cent of total production in Bhiwani district. The analysis of marketable and marketed surplus of pearl millet reveals that overall marketable surplus was $5343.25 \mathrm{~kg}$ per acre and $4630.25 \mathrm{~kg}$ per acre in Mahidergarh and Bhiwani districts, respectively. The results obtained are almost similar to the earlier results obtained by Sharma (2012).

From the above discussion, it was observed that there was no difference between marketed surplus and marketable surplus in both the districts. It was because no distress sale is recorded and no stock was retained by the farmers for the next year.

\section{Pattern of production and consumption}

Table 8 and 9 showed per farm pattern of production and consumption among different size groups. With the increase in the size of holding among the different component of the 
total consumption, Livestock consumption forms the major portion constituting 54.15 per cent and 51.63 per cent of total consumption followed by family consumption i.e. 30.68percent and 30.69 per cent in Mahindergarh and Bhiwani districts, respectively. The results obtained are almost similar to the earlier results obtained by Sharma (2012).

The higher quantity held for livestock consumption may be due to fact that number of animal per farm increased with the increase in size of holding as well as produce was infested by diseases which was not found suitable for family consumption, instead fed to the animals.

It was assumed that the Stover productivity was at 2.5 time that of grain yield, and it was the same across all state and season, which was the average of previous five years Stover to grain yield ratio. It was assumed that per capita consumption of 2004/05 level would be maintained by both urban and rural population in 2011 and 2020.With the increase in the size of holding among the different component of the total consumption, Livestock consumption forms the major portion constituting 54.15 per cent and 51.63 per cent of total consumption followed by family consumption i.e. 30.68percent and 30.69 per cent in Mahindergarh and Bhiwani districts, respectively.

\section{References}

Banafar, K.N.S., Thakur, N.K. and Gauraha, A.K. (2006). Marketing of mustard in Surguja district of Chhattisgarh. Journal of Agriculture Marketing, 49(1): 15-19.

Chauhan, S.A., and Kumar, S. (2010). Production, marketed surplus and postharvest losses in maize crop of India. Indian Journal of Agriculture Marketing, 24(2): 29-34.
Dhandhalya, M.G. and Shyami, R.L. (2009). Economic viability and marketing efficiency of semi-Rabi bajra: A case study of Sausahtra region in Gujarat. Economics Affairs Calcutta, 54(12): 19.

Goyal, S.K. and Berg, E. (2004). An analysis of markted surplus response of cereals in Haryana state of India. Indian Journal of Agriculture Marketing, 20(3): 253-268.

Kumar, P. (1999). Marketed surplus of different crops across farm size: A study in Haryana. Indian Journal of Agriculture Marketing, 54(4): 500-521.

Lal, R.C., Singh, J., Sharma, A. and Tyagi, D.B. (2003). A case study of wheat marketable surplus and marketing behavior of the farmers. Indian Journal of Agriculture Marketing, 17(2): 105110.

Nagraj N., Kundu K. K., Haldar S., Bantilan C. and Chandrakanth M. G. (2013). Baseline scenario of rainy season pearl millet in Haryana. Working paper series No. 40. Patancheru, (AP), India: International Crops Research Institute for the Semi-Arid Tropics 28.

Pant, D.C. and Hada, S. (2004). Marketing of maize in Rajasthan. Indian Journal of Agriculture Marketing, 18(1): 140-147.

Rao, D., Kumar, B., Bharath, K.A. and Mathew, B.D. (2003). A critical analysis trend in production, price and market arrivals of sorghum vs competing crops. Indian Journal of Agriculture Marketing, 17(1): 83-92.

Reddy, A., A., Parthasarathy Rao, P., Yadav O.P., Singh I.P., Ardeshna, N. J., Kundu, K. K., Gupta S.K., Rajan Sharma, Sawargaonkar,G., Malik D. P., Shyam Moses D. and Sammi Reddy K. (2013). Prospects for Kharif (Rainy Season) and Summer Pearl millet in Western India. Working Paper Series no. 36. Patancheru, (AP), India: 
International Crops Research Institute for the Semi Arid Tropics, 24.

Singh, A., Sharma, R.P. and Singh, V. (2008). A case study on economics of production and marketing of soybean in district Dewas (MP). Journal of Agriculture Marketing, 19(8): 23-27.

Srivastava, R. and Sahoo, R. (2006).
Marketable surplus and price spread of paddy for large farmer in Oorisa. Indian Journal of Agriculture Economics, 12(1): 385-386.

Tomer, B.S., Singh, V.K and Singh, D. (2006). Marketing of wheat in Haryana. Indian Journal of Agriculture Economics, 12(1): 418-419.

\section{How to cite this article:}

Kundu, K.K., Dinesh Kumar and Sumit. 2019. Production and Marketing Patterns of Pearl Millet in India with Special Reference to Haryana. Int.J.Curr.Microbiol.App.Sci. 8(08): 21522160. doi: https://doi.org/10.20546/ijcmas.2019.808.251 